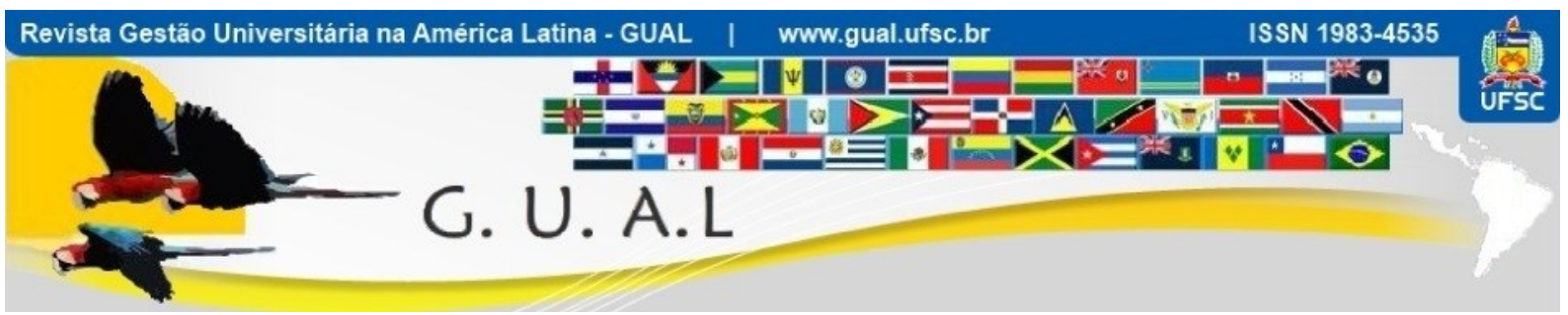

DOI: http://dx.doi.org/10.5007/1983-4535.2012v5n2p352

\title{
EDUCAR PARA O PÓS-HUMANISMO
}

\author{
Desembargador José Renato Nalini \\ Tribunal de Justiça do Estado de São Paulo \\ renatonalini@tjsp.jus.br
}

\begin{abstract}
RESUMO
O presente ensaio pretende discutir o problema do ensino jurídico a partir do recorte teórico do pós-humanismo. O objetivo, nesse sentido, é explorar os desafios práticos do momento contemporâneo e sua (in)compatibilidade com a vetusta formação dos bacharéis em direito, com ênfase na formação do magistrado. A metodologia adotada, para tanto, se fundou em pesquisa bibliográfica, em especial de textos produzidos por referenciais teóricos de outras áreas do saber, tendo em vista a importância de se discutir este tema a partir de enfoque multidisciplinar. Espera-se como resultado contribuir com o enriquecimento do debate em torno do ensino jurídico.
\end{abstract}

Palavras-chave: Educação. Pós-humanismo. Ensino jurídico. Formação dos magistrados.

Esta obra está sob uma Licença Creative Commons Atribuição-Uso. 


\section{INTRODUÇÃO}

A perplexidade foi um sintoma freqüente neste estágio civilizatório. Sintoma bastante evidenciado pelos intelectuais mais sensíveis durante as últimas décadas do Século XX. Uma centúria que assistiu a dois conflitos mundiais, a afirmações como "a morte de Deus", "a morte da História" e até "a morte do homem", deixou aturdidas as estruturas mentais solidificadas à luz de uma educação clássica. Chegou-se a sustentar o ingresso da civilização numa fase de pós-humanismo ou até de desumanidade ${ }^{l}$.

O universo jurídico impactou-se ante o fenômeno da "judicialização de todas as questões" e logo percebeu que os esquemas tradicionais se mostravam insuficientes ao enfrentamento dos presentes desafios. Escancaradas as portas do acesso à Justiça, logo verificou-se a inviabilidade de resposta oportuna e completa para todas as demandas. Não é só a pesada estrutura burocrática e a opção pelo ideal de segurança jurídica, a sobreviver no mundo da mais completa insegurança. Registrou-se ainda a instrumentalização do Judiciário por parte dos interessados em se valer de suas deficiências, notadamente a sofisticação ritual a gerar insuplantável lentidão de trâmites.

A proliferação normativa em nada atenua a morosidade. Ela derivou de uma série de fatores. O desprestígio do Parlamento, que passou a representar mais um complexo de interesses localizados e perdeu de vista o interesse comum, a urgência da resolução de problemas novos, insuscetíveis de terem sido pressentidos pela frágil capacidade previsiva dos legisladores. Surgiram inúmeras instâncias produtoras de comandos obrigatórios, a competir com a função inicialmente encarregada de estabelecer as regras do jogo. Bancos Centrais, Agências reguladoras, Comitês, Conselhos, tudo a gerar um panorama normativo incompreensível, ambíguo e contraditório.

O Governo - diretamente ou por suas várias exteriorizações - passou a normatizar de maneira intensa. O Parlamento, incapaz de cumprir a contento sua vocação original, passou a investir prioritariamente em sua função fiscalizadora. As normas por ele elaboradas passaram a ser respostas pontuais a questões tópicas. Ausente o seu caráter de generalidade, também não primaram por boa técnica. As leis perderam na pretensa precisão, para revestirem fisionomia ambígua, como é próprio ao fruto de compromisso entre os interesses em litígio. Para conseguir as maiorias ocasionais, transige-se até em princípios e passa a inexistir uma linha coerente na produção normativa.

\footnotetext{
${ }^{1}$ JÉRÔME BINDÉ, Para Onde Vão os Valores, Lisboa, Instituto Piaget, 2006, p.22.
} 
A turbulência na elaboração das regras em nada contribui para o cumprimento espontâneo das obrigações. Ao contrário, suscita conflitos, muitos deles contornáveis se houvera um quadro mais coerente no ordenamento. Tudo veio a desaguar no Judiciário, chamado a decidir temas para os quais a anacrônica formação jurídica não preparara seus profissionais. Não se imaginou que o final do milênio fizesse o julgador se preocupar com anencefalia, uso e destino de embriões, transgenia, cotas e ações afirmativas, transexualismo, delitos informáticos, ação de hackers, múltiplas vulnerações ao meio ambiente, democracia eletrônica e tantos outros temas sequer sugeridos nas aulas do Bacharelado. Aqui, os exemplos ainda são extraídos do Direito Romano, com a discussão entre Caio e Tício a respeito dos frutos caídos no terreno contíguo.

Não foram muitos os que se aperceberam dessa verdadeira revolução cultural e de seus reflexos na função encarregada de resolver conflitos. Tanto que a doutrina continuou a emitir lições calcadas na velha concepção das lides interindividuais e a explicar a decisão judicial à luz do silogismo e da subsunção. Era previsível o colapso que pôs em xeque a função jurisdicional e o juiz na alça de mira da sociedade brasileira. A mídia onipresente focou o Judiciário e nunca mais o abandonou. $\mathrm{O}$ espaço reservado às notícias do foro é testemunho de que o tema deixou de ser objeto da leitura especialista, para assumir a categoria de fato interessante para crescentes faixas de destinatários. Não é preciso recorrer a pesquisas científicas para concluir que a curiosidade em torno às questões judiciais é compartilhada por jovens e idosos, por eruditos e rústicos. Afinal, se antigamente era rara a necessidade de se litigar, freqüentar hoje os pretórios é rotina. O demandismo é considerado índice democrático e os milhões de processos um termômetro do Estado de Direito.

Foi nesse contexto que se fez notável o criativo desbravador de novas sendas de resgate do Judiciário que é o Ministro SÁLVIO DE FIGUEIREDO TEIXEIRA.

\section{SÁLVIO E A EDUCAÇÃO DE JUÍZES}

Vocacionado à Magistratura, desde cedo o jovem Sálvio de Figueiredo Teixeira passou a pensar no futuro de uma carreira em risco. Assim como acontecera com o sacerdócio e com a medicina, a profisssão-juiz começou a ser questionada. Já não se convencem os consumidores da Justiça com a auréola de expressão de soberania estatal. Sentem necessidade de uma resposta jurisdicional pronta, oportuna, efetiva, eficaz. Não aceitam que, em nome da segurança jurídica, as demandas alcancem décadas. O ritmo da sociedade 
acelerou-se e o Judiciário permaneceu a cultivar a inércia, não apenas como princípio, mas como praxe administrativa aparentemente invencível.

Sálvio detectou a realidade com sua reconhecida perspicácia. O juiz contemporâneo precisa de outros atributos, além do conhecimento técnico. Não pode ser surdo ao clamor por justiça, nem cego à realidade brasileira. Apreendeu a urgência de uma preparação que viesse a superar as inconveniências de um recrutamento baseado na memorização de textos. Seleção que não prioriza a vocação, a ética, a capacidade de trabalho, a noção institucional do Judiciário, o consequencialismo, a coragem para decidir. Personagem cada dia mais chamado a intervir no convívio humano, o julgador precisa ser um profissional polivalente.

O corajoso mineiro não se limitou a refletir sobre um novo projeto para prover a nacionalidade dos juízes de que necessitava. Experienciou um auto-investimento em educação continuada e se aperfeiçoou no Centro de Estudos Judiciários de Portugal. Ali se desenvolve um consistente plano de preparação para a carreira e de formação permanente, baseado no êxito da iniciativa francesa. Há quase meio século a França dispõe de sua Escola Nacional da Magistratura, assim como oferece a toda a burocracia a sua Escola Nacional de Administração. Ninguém ali discute a indispensabilidade de um centro preparador de novos quadros. Baniu-se a álea do chamamento empírico, tão nociva a incluir no equipamento estatal pessoas não vocacionadas.

À medida em que alçava as naturais posições na Magistratura, Sálvio conferia correspondente afinco à sua vocação de formador de novos profissionais da Justiça. Foi alavanca eficiente à pioneira Escola da Magistratura de Minas Gerais, depois assumiu a Escola Nacional da Magistratura da Associação dos Magistrados Brasileiros. Promoveu encontros, seminários, congressos, editou obras e incentivou a multiplicação de agentes voltados a essa missão.

Líder natural e provido de uma personalidade sedutora, convencia instâncias as mais diversas a se interessarem pelo tema da educação judicial. Não absorvia tarefas, mas compartilhava o conhecimento e descobria as inclinações para direcioná-las a um efetivo aproveitamento de potencialidades. Espírito altaneiro, verdadeiramente superior, nunca deixou de agregar. Estava acima dos melindres, das vaidades, das ciumeiras tão presentes em todas as corporações.

Ao dirigir a Escola Nacional da Magistratura, congregou em torno dela pugilo razoável de estudiosos e praticamente percorreu o mundo, haurindo dos múltiplos sistemas os resultados suscetíveis de transplante e adaptação para a realidade brasileira. Os estudos 
decorrentes dessas visitas de trabalho germinaram uma substanciosa doutrina de educação judicial, área em que o Brasil pode agora competir com países considerados pioneiros e paradigmáticos.

Sua luta pela institucionalização da Escola Nacional de Formação e Aperfeiçoamento da Magistratura, hoje mantida pelo Superior Tribunal de Justiça, foi fundamental para a concretização do ideal há tanto acalentado. Fruto da convicção de que o exercício da jurisdição reveste gravidade tamanha, que reclama prévio empenho na preparação e não dispensa a perseverança num processo contínuo de aprimoramento.

De tudo isso cuidou o Ministro SÁLVIO DE FIGUEIREDO TEIXEIRA, sem deixar de exercer a jurisdição. Seus votos lapidares inspiram o dinamismo jurisprudencial que é espaço vivo de revisita por parte do intérprete. Integra o núcleo de consolidação do Superior Tribunal de Justiça e serve de parâmetro para extrair da nova ordem, instaurada a partir de 1988, todas as conseqüências democráticas pretendidas pela nacionalidade. É dele a afirmação de que o Código de Processo Civil Brasileiro possui a mais bela regra instrumental já editada no planeta: aquela contida no seu artigo 244: Quando a lei prescrever determinada forma, sem cominação de nulidade, o juiz considerará válido o ato se, realizado de outro modo, lhe alcançar a finalidade ${ }^{2}$.

O processo foi outra das paixões de SÁLVIO, pois é a ferramenta de que se servem os profissionais do foro para concretizar o justo. Sem instrumento adequado, o artífice não consegue realizar sua obra. A grande reforma do Processo Brasileiro se deve à sua pertinácia, lucidez e descortino. Em lugar de uma nova codificação, a envolver vaidades, sensibilidades e a natural resistência ao novo - pois a lei irrevogável na seara jurídica é a da inércia - afirmava ele preferir "comer pelas bordas". Alterações tópicas, mas factíveis. Aos poucos, nova configuração ao processo, que não pode deixar de se adaptar às profundas transformações da sociedade, impulsionadas pela tecnologia e pelo avanço das demais ciências. Foi uma das manifestações da sabedoria mineira, também presente em todas as suas falas, semeadas de simpatia e senso de humor.

As últimas décadas do século $\mathrm{XX}$ foram palco de fervilhante atividade impulsionada pelo Ministro SÁLVIO, para as inúmeras reformas pontuais do Código de Processo Civil.

\footnotetext{
${ }^{2}$ O dispositivo continua a merecer nota de rodapé na clássica obra de THEOTÔNIO NEGRÃO e JOSÉ ROBERTO FEREIRA GOUVÊA, o Código de Processo Civil e legislação processual civil em vigor, São Paulo, $41^{\mathrm{a}}$ edição, 2009, p.369, a citar o julgado inserto in RT 683/183.
} 
Tudo com vistas de tornar efetiva a promessa do constituinte de propiciar ao destinatário uma prestação jurisdicional oportuna, adequada e eficiente.

Se hoje no Brasil a preocupação com o preparo dos juízes, sua ética, seu comprometimento com a missão de implementar a Democracia, constitui tema recorrente e incluído em qualquer agenda, muito se deve ao tirocínio de SÁLVIO DE FIGUEIREDO TEIXEIRA. Sua disponibilidade, entusiasmo e habilidade para agregar servem e continuarão a servir como estímulo a que as atuais e futuras gerações prossigam numa tarefa que não possui termo final. É, verdadeiramente, uma endless task ${ }^{3}$, pois sempre haverá algo a se acrescentar a uma proposta consistente de prover a Nação de juízes melhores.

\section{COMO FORMAR JUÍZES?}

Assente que a Faculdade de Direito não tem a incumbência de fornecer juizes "prontos e acabados" para o Poder Judiciário, o mundo já se convenceu de que dessa missão deve se desincumbir a própria Justiça. A mais adequada via para isso ainda parece consistir na criação da Escola de Juízes. É a tendência universal e foi a opção do constituinte de 1988, reforçada quando da Reforma do Judiciário, introduzida pela Emenda Constitucional 45/2004.

Estruturada a Escola Nacional de Formação e Aperfeiçoamento de Magistrados, cumpre persistir na adoção de estratégias de formação que assegurem a eficácia de suas metas. A que se propõe uma Escola de Juízes? De que juiz o Brasil precisa? Existe consenso quanto ao modelo ideal de julgador? A resposta só pode ser negativa. Não existe a mínima viabilidade na padronização da silhueta do juiz brasileiro. Um pacto fundante que adota como princípio essencial o pluralismo, não se compadece com a tentativa de homogeneizar um profissional. De um complexo de qualidades poder-se-á delinear várias padronagens suscetíveis de caracterizar um julgador adequado. Mesmo porque, a persona juiz exerce vários papéis no seu desempenho profissional.

A Escola de Juízes não pode se converter numa réplica de Faculdade de Direito. Disciplinas jurídicas já foram transmitidas ao alunado durante cinco anos. Agora, é fazer o candidato a juiz pensar nos reptos que se antepõem a quem escolhe a missão de julgar como rotina para algumas décadas. A expectativa é a de que o aprovado em concurso permaneça na carreira por tempo suficiente para justificar o investimento que nele a sociedade fez.

Cabe indagar, entretanto: o que se espera de um juiz?

\footnotetext{
${ }^{3}$ Tarefa interminável, sem fỉm, citação freqüente na rotina do linguajar norte-americano. 
Que ele saiba julgar. Mas julgar é simplesmente fazer incidir a vontade concreta da lei a um caso formalizado em processo? Obviamente, outra resposta que só pode ser escusa. De operação tal se desvencilharia com rapidez e economia maiores a informática. Dispõe-se há décadas de inteligência artificial, cada vez mais inteligente e mais semelhante às aptidões exclusivamente humanas.

Um juiz é um solucionador de controvérsias. É alguém que, na prolixidade do ordenamento saberá encontrar a resposta menos aflitiva para os envolvidos. Aquela mais condizente com um ideal intuído de justiça que até pode não ser bem descrito, mas é sentido por qualquer criatura humana injustiçada. A injustiça, até em doses homeopáticas é veneno mortal, já se afirmou em obra clássica.

As habilidades requeridas a um julgador não diferem tanto daquelas exigíveis a profissionais munidos de responsabilidade em outras áreas. Um roteiro aproximado já foi oferecido por um estudioso dessas questões, o professor Roberto Aguiar. Houve uma inclinação preliminar do estudante ao escolher o curso de direito ante tantas ofertas da Universidade brasileira. Essa opção inicial, que reflete adesão ao universo ético - pois o direito é o mínimo ético de Jellineck - precisa ser acompanhada de persecução a outras habilidades, quais as de:

a) dialogar, jogar e clamar por ética num mundo marcado pela velocidade e ineditismo dos problemas;

b) acumular repertório dentro de um contexto multidisciplinar;

c) desenhar em sua existência caminhos éticos, opções políticas transformadoras e soluções inovadoras;

d) ser curioso, não se conformar com a primeira solução, não aceitar caminhos superficiais e contextualizar a questão ao invés de simplesmente adequá-la às formalidades legais ou ao entendimento dominante e hegemônico;

e) entender o mundo, promovendo uma consciência dinâmica do que o cerca;

f) entender o outro;

g) entender a si mesmo;

h) se comunicar, isto é, perquirir o sentido mais profundo nos textos e contextos, tornando-se capaz de recriar, ressemantizar, construir imaginários, além de interpretar e redigir;

i) entendimento e releitura das normas;

j) entender, interferir e solver conflitos;

k) deslocar o olhar;

1) disciplinar-se; 
m) formar repertório;

n) captar o novo;

o) legislar;

p) negociar;

q) arbitrar;

r) pesquisar;

s) fundamentar e argumentar;

t) jogar;

u) operar com as técnicas jurídicas tradicionais;

v) trabalhar com as tecnologias;

w) compreender novos problemas;

$\mathrm{x})$ trabalhar com outras línguas;

y) agir e pensar multidisciplinarmente ${ }^{4}$.

Nem todos conseguem adquirir - ao menos com o mesmo grau ou desenvoltura todas essas habilidades. Mas o quadro é elucidativo e pode conter reiterações. É a enunciação de alguns atributos hábeis a auxiliar o juiz a bem desincumbir-se de sua opção existencial.

A indagação que persiste é: como alcançar esse objetivo?

\section{APRENDER A PENSAR}

O bacharelado ensina a memorizar. A receita é acumular informações para poder sacálas quando alguém é solicitado a responder os testes de múltipla escolha das inúmeras avaliações vindouras. Registra-se uma verdadeira paranóia quanto ao Exame de Ordem, a seleção feita pela OAB para credenciar os bacharéis. Um vestibular às avessas que impõe ao formado recorrer a novos cursinhos para relembrar o conteúdo do qüinqüênio de aprendizado jurídico. Decorar, portanto, é a regra de ouro. A elaboração de rankings de Faculdades de Direito faz com que estas se concentrem no treino do alunado a um bom desempenho. A performance da escola é o que garantirá a continuidade do empreendimento.

A transmissão do conhecimento é conteudista e compartimentada. Disciplinas estanques e desvinculadas são ministradas por docentes preservados em seu isolacionismo e só por exceção aptos a desenvolver programas de outras matérias ou a elaborar conteúdos intercambiáveis. Em regra, não se relacionam as disciplinas entre si. Não dialogam. Não

\footnotetext{
${ }^{4}$ ROBERTO AGUIAR, Habilidades: ensino jurídico e contemporaneidade, Rio de Janeiro, DP\&A, 2004, p.17/18.
} 
conversam. Cada qual cuida de seu próprio território e desconhece, em regra, o que se passa no quintal alheio.

A Escola da Magistratura não pode laborar nessa mesmice. Sua proposta não é disseminar noções de direito para diletantes, senão prover a República de magistrados capazes de escorar o Estado de Direito de índole democrática. Servos diligentes de um pacto fundador voltado à edificação de uma pátria justa, fraterna e solidária.

Ao paradigma curricular de rigidez positivista há de suceder um parâmetro de perspectiva epistemológica aberta. O juiz não pode conhecer apenas direito e sua técnica. Necessita aptidão para navegar por temas transversais, com ênfase na filosofia, na psicologia, na história, na economia, na ética e nos valores. O direito é ferramenta insuficiente para a resolução de todas as aflições humanas. Precisa de permanente e intensa interligação com outras formas de conhecimento, servir-se de metodologia interdisciplinar e transdisciplinar.

Juiz existe para decidir e nem sempre o conhecimento da lei é suficiente para proferir o julgamento mais justo. Sentenciar é decidir com sentimento e o fruto da razão precisa ser acompanhado de habilidades sensitivas, psicológicas, sociais, afetivas e estéticas.

O consequencialismo não pode estar ausente das preocupações dos formadores de juízes. Está superada a era do fiat justitia, pereat mundus ${ }^{5}$. A repercussão no entorno, os resultados concretos da implementação da vontade judicial não podem ser desconsiderados. $\mathrm{O}$ juiz é responsável por seus julgamentos.

O ideal da pacificação é o objetivo, o processo é o meio. O caminho não pode ser mais importante do que a chegada. Inviável converter-se a ferramenta em finalidade. Por isso o juiz do século XXI haverá de munir-se de dose suficiente de paciência e humildade, para obter soluções menos traumáticas. Haverá de preferir sempre a conciliação, em lugar da elaboração de decisões eruditas e sofisticadas, cujo destino será os repertórios jurisprudenciais, mas que deixam seqüelas dolorosas para os protagonistas do drama judicial. Ser reconhecido como proficiente para galgar posições na carreira não pode sobrepor-se à missão de harmonizar a sociedade. O juiz existe para a sociedade, não esta para ele ou para servir aos seus desígnios.

Para um Judiciário constantemente repreendido pela sociedade em virtude de sua lentidão, há comandos fundantes que o juiz não poderá ignorar. O mais enfático dentre eles é o princípio da eficiência, incluído no rol daqueles exigíveis à Administração Pública dez anos

\footnotetext{
${ }^{5}$ Faça-se justiça e pereça o mundo. 
depois de promulgada a Constituição do Brasil ${ }^{6}$. Como se fora destinado direta e exclusivamente para o Poder Judiciário, a função estatal menos afinada com as modernas estratégias de aceleração dos serviços públicos. Eficiência, publicidade, ética, moralidade administrativa na gestão da Justiça, a tudo isso deverá estar atento o juiz brasileiro nesta primeira década de um novo século e de um novo milênio.

Foi-se o tempo em que o juiz se satisfazia com o uso dos códigos e neles encontrava todas as respostas para as demandas submetidas à sua apreciação. Hoje o Direito não pode prescindir de consistente exegese que leve em consideração inúmeros fatores metajurídicos. Há de se familiarizar o juiz com um novo conceito de teoria geral do Direito, hábil a despojar o universo jurídico de seu aparelho técnico e atingir sua essência. Cumpre "descobrir seu significado metajurídico e os valores que ele deve perseguir, seu sentido com relação a uma visão total do homem e do mundo"7. Em síntese, e sem arrogar a pretensão de empalmar tudo o que se mostra conveniente pensar em termos de preparação de juízes, impõe-se ao educador judicial formar pessoas que pensem. O que não equivale a criar um corpo técnico submisso à letra da lei, na fiel observância de seu texto e total alheamento ao seu espírito. Personagem este que poderá envergar a toga, mas não será um verdadeiro juiz.

\section{UM JUIZ HUMANISTA}

Não é nova a preocupação com um projeto educacional voltado a produzir humanistas. Não se fala nada de novo e caberia invocar Lavoisier para recordar que nada se cria, tudo se transforma. Impregnar a educação de humanismo foi uma das pretensões de Montaigne, para quem era preferível uma cabeça bem feita do que uma cabeça cheia ${ }^{8}$. A mente repleta de erudição pode gerar arrogância.

Montaigne sabia ser difícil modificar as propensões naturais. Mas já repudiava - isso em $1^{\circ}$ de março de 1580 ! - a tática de ministrar igual lição e disciplina para vários espíritos naturalmente diferentes uns dos outros pela inteligência e pelo temperamento?.

\footnotetext{
${ }^{6}$ O princípio da eficiência foi incluído no caput do artigo 37 da Constituição da República pela Emenda Constitucional n.19, de 4.6.1998.

${ }^{7}$ JEAN-LOUIS BERGEL, Teoria Geral do Direito, São Paulo, Martins Fontes, 2006, p.XX.

8 MICHEL DE MONTAIGNE, Ensaios, São Paulo, Abril Cultural, 1972, p.81. Textualmente: "para se enriquecer e adornar por dentro para um rapaz que mais desejaríamos honesto do que sábio, seria útil que se escolhesse um guia com cabeça bem formada mais do que exageradamente cheia e que, embora se exigissem as duas coisas, tivesse melhores costumes e inteligência do que ciência. Mais ainda: que exercesse suas funções de maneira nova".

${ }^{9}$ MICHEL DE MONTAIGNE, op.cit., idem, ibidem.
} 
Compreensível que, nessa tentativa de homogeneizar o que é genuinamente heterogêneo, de uma multidão de crianças, somente duas ou três tirem do ensino o devido fruto ${ }^{10}$.

O ensino padronizado, na repetição monocórdica das verdades indiscutíveis, forma espíritos tolhidos, incapazes de enfrentamento do inesperado. O modelo pedagógico vigorante é gerador de um ser humano "servo e cativo de ensinamentos estranhos. Tanto nos oprimiram com as andadeiras, que já não temos movimentos livres. Vigor e liberdade extinguiram-se em nós: "nunca se dirigem por si próprios",11.

A receita do autor dos Éssais ainda se mostra atual para o educador do século XXI: "Tudo se submeterá ao exame da criança e nada se lhe enfiará na cabeça por simples autoridade e crédito. Que nenhum princípio, de Aristóteles, dos estóicos ou dos epicuristas, seja seu princípio. Apresentem-se-lhe todos em sua diversidade e que ele escolha se puder. E se não o puder fique na dúvida, pois só os loucos têm certeza absoluta em sua opinião "12.

Montaigne evidencia singular apreço à dúvida. À dúvida metódica, suspensão provisória do juízo até se alcance o convencimento. Não a dúvida sistemática, paralisante e neutralizadora de qualquer atitude. Quantos males causam os juízes indecisos. Aqueles que, por carentes de firmeza, não sabem o que fazer. Também são nefastos os absolutamente convictos desde o primeiro impulso. É salutar a hesitação, desde que breve, não ultrapasse o razoável. A recomendá-la, Montaigne invoca Dante: "não menos que saber, duvidar me apraz $^{, 13}$.

Cem anos após o ciclo vital de Montaigne nascia Charles-Louis de Secondat, Barão de La Brède e de Montesquieu ${ }^{14}$ que, em seu Do Espírito das Leis, também cuidou de educação. Lembra que "as leis da educação são as primeiras que recebemos. E, como elas nos preparam para sermos cidadãos, cada família particular deve ser governada de acordo com o plano da grande família que abrange todas ${ }^{, 15}$.

Atribuir a responsabilidade pela educação à família, sociedade e Estado, conforme reza o pacto republicano ${ }^{16}$ é proposta longeva, portanto. Montesquieu reconhecia a superioridade da educação entre os povos antigos, cujo princípio era a virtude e que possuía

\footnotetext{
${ }^{10}$ MICHEL DE MONTAIGNE, op.cit., idem, ibidem.

${ }^{11}$ MICHEL DE MONTAIGNE, op.cit., idem, ibidem, a invocar Sêneca.

${ }^{12}$ MICHEL DE MONTAIGNE, op.cit., idem, p.81/82.

${ }^{13}$ MICHEL DE MONTAIGNE, op.cit., idem, p.82, na citação de Dante: Che non men che saper dubbiar m'aggrada.

${ }_{14}^{14}$ MONTESQUIEU nasceu em 18.1.1689, no Castelo de La Brède, ainda existente a cinco léguas de Bordeaux.

${ }^{15}$ MONTESQUIEU, Do Espírito das Leis, São Paulo, Abril Cultural, 1973, p.59, a citar Aristóteles, Política, livro V, capítulo IX..

${ }^{16}$ Artigo 205 da Constituição da República Federativa do Brasil.
} 
como vantagem nunca ser desmentida. Os ensinamentos da primeira infância continuavam válidos até o final da existência. Já a educação de seu tempo era criticada: "Hoje, recebemos três educações diferentes ou contrárias: a de nossos pais, a de nossos mestres e a da sociedade. O que nos é dito na última destrói todas as idéias das primeiras" ${ }^{17}$. O contraste entre o que se prega e o que se vive já merecia a repulsa do pensador. Severo ao julgar seus coetâneos: "não é a nova geração que se degenera; essa só se perde quando os homens maduros já estão corrompidos" "18.

Um salto de quase quinhentos anos separa as reflexões de Montesquieu daquelas de John Dewey, notável educador contemporâneo ${ }^{19}$. Sua proposta pedagógica não pode ser ignorada por todos os que se detêm sobre a mais adequada fórmula de se formar um juiz. Pois existe um componente moral a impregnar todo o seu projeto, circunstância que confere relevo e atualidade à missão da Escola de Juízes.

Sua filosofia da educação "não é a aplicação exterior das idéias já feitas a um sistema de prática escolar que tivesse origem e metas radicalmente diversas: é apenas uma reformulação explícita dos problemas da formação de uma mentalidade reta e de bons hábitos morais, tendo-se em vista as dificuldades da vida social contemporânea" ${ }^{20}$. O próprio título do livro - Democracia e Educação - denota a centralidade do pensamento deweyano: atingir a democracia é meta condicionada ao implemento de uma educação conseqüente.

Educação é experiência. É um processo de vida. Vida presente, não para o futuro. O sistema atual incute no discente uma perspectiva longínqua: educa-se para o porvir. Enquanto educar, para Dewey, é uma reconstrução da experiência. Textualmente, a educação é um "processo de reconstrução, de reorganização da experiência, pelo qual lhe percebemos mais agudamente o sentido, e com isso nos habilitamos a melhor dirigir o curso de nossas experiências futuras" ${ }^{21}$. Ao se pensar em educação continuada, não há como deixar de absorver tal ensinamento. Pois educação é crescimento e não há termo final para que um juiz continue a crescer em experiência e sabedoria.

O aspecto experiência é vital para o bom êxito de uma Escola de Juízes. A ciência jurídica o candidato a juiz já possui. Adquiriu-a no Bacharelado. Na Escola da Magistratura há de se propiciar experiência judicial. E não apenas no mero treino fíctício, como na

\footnotetext{
${ }^{17}$ MONTESQUIEU, op.cit., idem, p.61.

${ }^{18}$ MONTESQUIEU, op.cit., idem, p.62.

19 JOHN DEWEY nasceu em Birlington, Vermont, em 20.10.1859 e morreu em 2.6.1952, em Nova Iorque. É considerado um dos Pais do Pragmatismo norte-americano.

${ }^{20}$ JOHN DEWEY, Democracia e Educação, São Paulo, Companhia Editora Nacional, 1979, p.364.

${ }^{21}$ JOHN DEWEY, op.cit., idem, p.8.
} 
superada realização de júris simulados. Mas experiência efetiva, na prática rotineira de fazer justiça. Não se pode dispensar o entusiasmo e idealismo dos jovens com exercícios desprovidos de resultado prático. Impõe-se aproveitar desde logo a sua vontade para corrigir as injustiças, no seu grande espetáculo da multiplicação.

Instigante a postura de John Dewey, ao salientar que o crescimento do educando só é viável se houver imaturidade, dependência e plasticidade. Os dois primeiros conceitos quase sempre refletem uma carga pejorativa. Imaturidade não é despreparo, falta de maturidade ou sensatez, senão abertura para a possibilidade. Maturidade como expressão intercambiável com potencialidade.

Todo juiz continua a protagonizar a condição de um ser potencialmente crescente. Quem poderá afirmar que já aprendeu tudo o que é necessário para bem julgar o semelhante?

Dependência é a situação de abertura a novas perspectivas, pois a auto-suficiência igualmente geraria arrogância. Um profissional que se considere perfeito e acabado nunca aceitaria contribuição de espécie alguma para uma reciclagem ${ }^{22}$. A dependência, sob esta vertente, significa mais uma potencialidade. A predisposição para o crescimento, para amealhar novos conhecimentos e, principalmente, novos olhares para situações idênticas ou análogas. Ou abertura para penetrar em situações novas e inusitadas.

Plasticidade não é muito diferente em sua concepção de capacidade de aprender com a experiência. Poder-se-ia falar em permeabilidade, pois o educando curioso e interessado é como uma esponja que absorve tudo o que lhe é transmitido ou que possa acessar espontaneamente.

Muitos benefícios acarretará para a formação de juízes a revisita a todos os clássicos da pedagogia - e não houve pensador que se não detivesse nessa alavanca propulsora do aprimoramento social que é a educação - e, com destaque, a releitura de John Dewey. Algumas de suas idéias guardam pertinência íntima com as necessidades detectadas pelos especialistas no processo de preparo de julgadores.

Mencione-se, por exemplo, a individualidade inconfundível de cada juiz. Numa nação continental composta por várias origens étnicas, várias culturas, diferentes níveis de desenvolvimento, é natural a multiplicação de perfis judiciais. Tudo compatível, como já se mencionou, com o princípio do pluralismo. Pois Dewey propunha um projeto - dificílimo,

\footnotetext{
${ }^{22}$ Particularmente não aprecio este verbete para conceituar a formação complementar de um profissional, com vistas à sua atualização e aggiornamento. Mas ainda não se formulou uma expressão substitutiva e eloqüente para caracterizar esse programa desenvolvido para reciclar os discípulos da educação permanente.
} 
quase utópico - de educação individualizada. Cada profissional merece uma atenção singular, respeitadora de suas aptidões, talentos, inclinações, filosofia/ideologia, história pessoal e até idiossincrasia.

Identificar a vocação do juiz para melhor desincumbir-se de funções que podem variar, diante da complexidade do aparelho judiciário, é assegurar que ele protagonize um desempenho mais proficiente ${ }^{23}$. A angústia de julgar, de resolver questões intrincadas e aflitivas, deve ser atenuada mediante possibilidade de atuar em assuntos da preferência ou especialidade do julgador. Já houve tempo em que os tribunais se obstinavam na política irracional de afastar o juiz da jurisdição de sua predileção. Com evidente prejuízo para o rendimento da Justiça e sem trazer realização completa para o profissional encarregado de concretizá-la. Pondere-se ainda que a especialização parece uma tendência irreversível. Se desde logo se denota a inclinação de um juiz para determinada área, por que não direcioná-lo para um aprofundamento naquilo que realizará com satisfação e prazer?

Outra vertente da pedagogia deweyana é a intensa preocupação com a moral. Nos tempos pós-morais, em que os valores parecem esgarçados, a nacionalidade abomina praxes que tangenciam a falta de ética. Basta o exemplo de outros setores, infelizmente contaminados por um chocante despudor. A Justiça é o bastião derradeiro da esperança dos desalentados. Quando decepciona por mácula ética, sepulta o resquício de ânimo que nutre o desvalido. A sua falha moral é mais deletéria. Os juízes sabem disso. São providos de responsabilidade acrescida perante os demais operadores do direito, mas são também atingidos pela incerteza desta era. Era em que a incerteza é a única certeza.

Quem poderá negar que “o século XX colocou dolorosamente em dúvida as nossas certezas respeitantes à sociedade, à história, ao homem? A crise contemporânea dos valores não é apenas a dos quadros morais tradicionais legados pelas grandes correntes religiosas; é igualmente a dos valores laicos que os vieram substituir (ciência, progresso, emancipação dos povos, ideais solidaristas e humanistas). A monstruosidade, que imprimiu a sua marca no

\footnotetext{
${ }^{23}$ O Poder Judiciário no Brasil não é um sistema singelo. Ao contrário: duas Justiças Comuns, uma estadual e outra federal e três Justiças Especializadas: a Laboral, a Militar e a Eleitoral. Quatro graus de jurisdição, desde a primeira instância até a cúpula da Justiça, corporificada pelo STF. Há possibilidade de opção por várias especialidades, notadamente nas jurisdições comuns: cível, criminal, com destaque para o setor de Inquéritos Policiais, Júri, Execuções Criminais, Varas Especializadas em determinados delitos, jurisdição menorística, consumerística, tributário-fiscal, comercial, previdenciária, Juizados Especiais, Fazenda Pública, Registros Públicos, etc. A tendência à especialização requer uma formação também específica, insuficiente o preparo abstrato e generalizante de antanho.
} 
século XX, parece ameaçar outra vez o nosso futuro",24. Diante de ameaças, não cabe sucumbir, senão reagir.

Ora, John Dewey, há mais de cinqüenta anos, propôs uma educação moral. Entendia que "a disciplina, a cultura, a eficiência social, o aperfeiçoamento individual, a melhoria do caráter, são apenas aspectos do desenvolvimento da capacidade de nobremente participar-se de uma tal experiência bem equilibrada. E a educação não é um simples meio para essa vida. A educação é essa vida. Manter a aptidão para essa educação é a essência da moral. Pois a

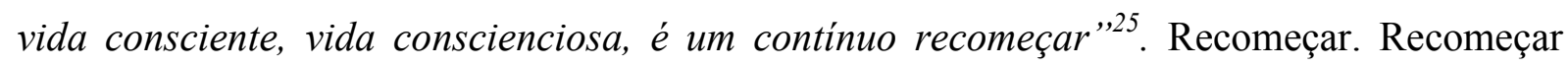
sempre. Rotina a que se vêem obrigados os juízes a se submeter. Pois a cada processo findo, outro estará à espreita para reclamar sua atenção, sua consciência e, principalmente, sua decisão.

A experiência da educação de juízes é o treino incessante para produzir justiça. Bem intangível, que só se experimenta quando alvo de seu antípoda: a injustiça. Provar do injusto é o que leva o ser humano a prezar a concretização do justo. A essência da moral do século XXI é propiciar a cada juiz a aptidão para uma educação permanente. Projeto que não pode restar entregue a um grupo fechado de especialistas, mas que deve merecer a participação de todos. Primeiro, do próprio ser educando. Ele é que deverá avaliar o ritmo, o conteúdo, sopesar seus interesses, inclinações e talentos. Reconhecer sua fragilidade, a requisitar investimento maior de esforço e dedicação. Mas procurar apreender o verdadeiro sentido de uma vocação que só existe para resolver problemas alheios. Não os próprios. Os do outro.

A sociedade também não pode ser excluída desse grande programa. Ela é a destinatária da Magistratura. Corpo selecionado de julgadores que somente existe para servila. A sociedade tem todo o direito de participar da formação desses profissionais e de se posicionar sobre o perfil da judicatura, seu futuro e os rumos que ela deva tomar, para melhor servir aos ideais da Justiça.

Para a consecução desse projeto, as idéias dos filósofos da educação mostram-se pertinentes e continuam atuais, malgrado elaboradas há décadas, ou há séculos. A mutação célere e profunda - a que submetida a vida social, faz com que a realidade não possa representar um sistema inerte e acabado. Como diz Dewey, "a inteligência garante ao homem capacidade para criar condições de sua própria experiência" ${ }^{26}$. Experiência voltada ao

\footnotetext{
${ }^{24}$ JÉRÔME BINDÉ, op.cit., idem, p.22.

${ }^{25}$ JOHN DEWEY, op.cit., idem, p.395.

${ }^{26}$ MARCUS VINICIUS DA CUNHA, John Dewey: uma filosofia para educadores em sala de aula, Petrópolis, Vozes, 2002, p.20.
} 
crescimento moral. Este é um processo em que o homem se torna mais racional, mais social e, finalmente, mais moral.

A criatura interessada em tornar-se mais ética será predestinada a também exercer de maneira mais responsável todas as suas funções. A cidadania, a profissão, a situação familiar, tudo merecerá um salto qualitativo. Os hábitos morais não se distinguem do caminho da virtude, valor adquirido paulatinamente, na reiteração de práticas consideradas boas. Dentre estas, vale ressaltar a humildade, tão significativa para o juiz.

Em país de desigualdades, quem estiver provido de um grau minúsculo de autoridade pode ser levado à prepotência e a uma exagerada auto-estima. A educação continuada à base da experimentação moral mostrará ao educando a fragilidade da condição humana e o efêmero das gloríolas terrenas.

A débil primícia dentre as espécies, o caniço pensante que só tem um encontro marcado - aquele democrático abraço da morte - não tem certificado de garantia. A História é repleta de exemplos de virtuosos que se tornaram pecadores e de infratores que se regeneraram ${ }^{27}$. Há um misto de desconforto e de esperança. Nada é para sempre, senão a morte. Por isso é que se impõe a vigilância permanente. Não transigir com o mal. Não relaxar. Não ser leniente para consigo mesmo.

Tudo passa sobre a Terra. Vão-se os cargos, as pompas, a tática das homenagens. Fica o bem praticado, a consciência do dever cumprido, a convicção de haver feito o melhor, a despeito das limitações e insuficiências próprias a qualquer integrante da espécie.

O projeto de formação integral do juiz brasileiro nasceu do idealismo de educadores como SÁLVIO DE FIGUEIREDO TEIXEIRA e outros tantos devotados cultores da tese hoje vitoriosa: a imprescindibilidade de uma educação judicial em caráter permanente. A fórmula para garantir o rejuvenescimento da Magistratura é convencer o juiz-educando de que essa renovação é um processo endógeno. Cada qual sabe onde está o interruptor mágico, acionável só pelo próprio interessado, que o converterá num entusiasta autodidata, na busca incessante de atingir a plenitude.

Todos ganharão com isso: a cidadania, a nacionalidade, a Justiça, a Democracia. Todavia, o próprio educando não será o menos beneficiado. Ele crescerá como pessoa e estará mais próximo à plenitude.

\footnotetext{
${ }^{27}$ Para a primeira hipótese, cite-se o Rei Davi. Para a segunda, o industrial Schindler, que salvou mais de um milhar de judeus e que foi celebrizado no filme "A Lista de Schindler".
} 